\title{
A Development of the Sufficiency Economy Philosophy Online Lessons for Sustainable Learning
}

\author{
C. Waree
}

\begin{abstract}
The goals are: to develop and discover efficiency of the sufficiency economy philosophy online lessons for sustainable learning to meet with criteria at $80 / 80$ and to study satisfaction level of students by using the sufficiency economy philosophy online lessons for sustainable learning. The target group herein was 40 students who studied in the Academic year of 2014 and interested in online registration. The target group was determined by using purposive sampling. Tools used in this research were 20 items of post-test contained in online lessons, student's satisfaction evaluation form towards online lessons usage. Data analysis was conducted to find the efficiency of online lessons as defined by criteria at 86.50 / 86.00 and student's satisfaction level towards online lessons usage of 40 students. The obtained mean was 4.56 and the standard deviation was 0.64 . The results showed that the efficiency of the sufficiency economy philosophy online lessons was at 86.50 / 86.00 that was higher than defined criteria at $80 / 80$. In addition, an Overall satisfaction of target group was in the highest level with the mean of 4.56 and S.D. at 0.64 .
\end{abstract}

Index Terms-Online lessons, the sufficiency economy philosophy, sustainability of learning, higher education.

\section{INTRODUCTION}

Education is considered as an essential tool for developing humans' knowledge and quality as well as improving their potential and competency. According to development plan for expanding management of basic education and emphasis on educational management in all levels and systems including formal education, non-formal education, and informal education, as well as Section 22 of National Education Act B.E. 2542, it is clearly stipulated that educational management must be under the principle that students should have abilities on learning and self-development. In addition, students must be considered as the most important element. Educational management process must reinforce students to develop naturally with full potential. Students and teachers may learn together from instructional media and technology sources whereas learning can be managed every time and everywhere. To manage education in this manner, Prawet Wasee [1] proposed that information technology should be more applied that was consistent with Kanchit Malaiwong [2] who mentioned on information technology that there teachers and students should have some opportunities to learn how to use information technology as the tool for perceiving news and knowledge through self-earning or two-way communication with teachers or colleagues.

Manuscript received October 12, 2018; revised January 31, 2019.

Chaiwat Waree is with the Faculty of Education of Suan Sunandha Rajabhat University, Thailand (e-mail: chaiwat.wa@ssru.ac.th).
Currently, the use of instructional media or online media on internet network is increasingly preferred that is consistent with rapid expansion of internet connection of several educational institutes throughout the world due to advantages of internet media in providing information that cannot be provided by other types of media to students. Moreover, another important factor causing online lessons to become popular is capability of technology on internet network in displaying multimedia, for example, messages, voice, photos, graphics, and motion pictures. In addition, it is also convenient for updating information at any time [3].

Current educational management of Thailand should be moral-based knowledge. Current government has tried to stimulate social development and social problem solving by restoring educational management policy for developing humans to have ethic strength and moral-based knowledge. In addition, the Philosophy of Sufficiency Economy is also applied to living of Thai people as the solution of Thai society because it has been realized that the current situation with political reform is caused by the problem on deterioration of morality, ethics, values, democratic way, disharmony, lack of unity and conformity, etc. All fields of current Thai society are full with talented persons but lack of morality leading to corruption, crisis, and competitive for personal success and happiness. Current Thai society lacks of common responsibility, assistance, and kindness Moreover, current Thai people abandon surrounding people and increase consumption they have to destroy natural resources and environment without realization. Simultaneously, their quality of life is unstable and weak because they are unable to rely on themselves physically and mentally as well as unable to become the supporters for society.

Most learning processes held in schools emphasized on academic development and successful reward in the form of exam score, grade, higher education, shield, and medal. Such kind of success is considered as unreal success in lieu of real quality in all fields of students. Through that king of success, students learn to receive in higher level than giving and they learn how to compete to take material and financial advantage for themselves in lieu of building their value with merit or they may learn to develop people for responding to capitalism's business system with expectation on better position and salary of learning for discovering and improving their value and society. They will place a premium on money, materials, and consumption in lieu of reality, merit, and esthetic. They learn through shortened learning process in the form of tutoring in lieu of learning how to think and practice practically for connecting with other things. Consequently, students will lack of actual knowledge and ability to of holistic thinking hindering them from connecting all fields of 
knowledge. They will lack of skills for working and solving problems (They cannot think and work by themselves hindering them from relying on themselves and becoming the supporters for other persons).

In the occasion of the 60th Anniversary Celebration of His Majesty's Accession to the Throne, Thai people mutually agreed to learn and implement the Philosophy of "Sufficiency Economy" under the royal initial with realization on His Majesty the King's kindness. They also believed that this philosophy would lead them to happiness for themselves, their families, communities, and nation.

Moral-based knowledge policy and Philosophy of Sufficiency Economy are considered as the same practice that is unable to be separated. People will learn how to be sufficient if they realize on natural rules and rules of three characteristics of existence. They will be able to stop their selfishness and realize that they are a part of nature. Since all sectors of natural elements are related to one another, destroying any balance will affect to other sectors wholly or partially. After realizing, they will express themselves to the world and other human beings appropriately without causing any persecution, intrusion, imbalance, or sorrow against any human being, animal, plant, water, soil, etc. This kind of morality is admirable yielding both personal and common benefits and happiness to

Reinforcing everyone, especially, juveniles in basic education level, on moral-based knowledge and implement the Philosophy of Sufficiency Economy is considered as another important solution for Thai society and the world. As a result, there should be the study figuring out which process will reinforce morality of students based on the Philosophy of Sufficiency Economy efficiently. Consequently, juveniles will be able to live their lives under the Philosophy of Sufficiency Economy.

From such reason, the researcher was interested in utilizing innovation and electronic media to convey a development of the sufficiency economy philosophy online lessons for sustainable learning.

\section{OBJECTIVES}

To develop the sufficiency economy philosophy online lessons for sustainable learning to gain efficiency at 80/80 and achieve better level of student's satisfaction.

\section{HYPOTHESIS}

The sufficiency economy philosophy online lessons for sustainable learning had efficiency level at 80/80 according to standard criteria and student's satisfaction level towards the sufficiency economy philosophy online lessons was in high level.

\section{SCOPE OF RESEARCH}

Populations used in this research was consisted of 2,450 students who were students of Suan Sunandha Rajabhat University in all years.

Target group used in this research on the sufficiency economy philosophy online lessons for sustainable learning was consisted of 250 students who were students of Suan Sunandha Rajabhat University in all years obtained by using purposive volunteer sampling.

\section{RELATED DOCUMENTS AND RESEARCHES}

Russett studied on effects caused by the use of e-mail of undergraduate students and changes on the use of electronic services of graduate students. The results revealed that there should be integration of educational technology in curriculums for managing instruction. In addition, there should be practices on e-mail skills between teachers and students. The research reflected that students were able to express their opinions freely that could not be happened through other instructional methods. This research concluded that e-mail should be used by students and teachers [4].

Casey studied on Surfing in the world of Information of Teachers and Students via Computer Network of teachers designed by California State University for teachers and students. From the study conducted by participants, it was found that students were more enthusiastic and everyone searched for information and they seemed to use home computers increasingly [5].

Laroe studied on practical courses changing by conducting the research with 1st - 3rd year students of University of Missouri and found that implementation of internet in learning could improve teacher's instruction efficiently [6].

Weerasak Pongcharoen studied on the relationship among attitudes of students, motivation, learning characteristics, and learning styles affecting to learning achievement of web-based instruction in the form of distance learning. The results revealed that there was no significant difference among learning achievement and other factors. However, from observation, it was found that students were amused with web-based instruction and they were able to control themselves with motivation and high expectation from web-based instruction. Students were more interested in checking their grades via e-mail than communicating with teachers in classrooms. Moreover, the researcher also proposed and suggested that there should be some instructional activities with students in order to control them more efficiently.

Brown (1998, referred by Weerasak Pongcharoen, 2004, page 21) studied on effects of data structure in World Wide Web and student's data recall. The results revealed that lessons with linear searching route gave the best effect for recalling student's data [7].

From domestic and international researches on the use of online lessons, it could be concluded that developed online lesson was able to develop students properly. When comparing pre-learning result and post-learning result, it was found that post-learning achievement of students was better than pre-learning achievement. When comparing with normal instruction, it was appeared that learning achievement of students who learned via online lessons was higher than that of students who learned via normal instruction. In addition, after learning via online lessons, students also had good attitude and opinion towards online lessons. Their behavior expressed during learning via online lessons was 
also positive towards instruction via online lessons.

Suda Julasawake conducted the research on Observation and Evaluation on Implementation of the Philosophy of Sufficiency Economy in Educational Institutions of Inspection Area 13 of Academic Year of 2007 and found that educational institutions implementing the Philosophy of Sufficiency Economy applied activities or projects related to sufficiency economy, for example, implementation of the Philosophy of Sufficiency Economy on management process in schools and implementation of the Philosophy of Sufficiency Economy in managing instructional activities [8].

Koset Duang-inthorn conducted a research on "Opinions of School Administrators, Teachers, and Students concerning the Educational Procedure in Cultivating Morality into Students in Secondary Schools under the auspices of the Department of General Education in Bangkok Metropolis". The objective of this research was to study on and compare opinions of school administrators, teachers, and students on teaching methods, problems, and obstacles on cultivating morality into students in secondary schools under the auspices of the Department of General Education in Bangkok Metropolis. The results revealed that the method that was mostly preferred by schools for cultivating morality in to students was classroom teaching followed by students training under projects, students' activities, and school environmental management. Emphasis on ethic characteristics was ordered as follows sacrifice, generosity, and abstaining from moral misconduct whereas school administrators, teachers, and students had not different opinion on cultivating morality into students. The crucial problem and obstacle were excessive number of students per classroom [9].

Weera Pansup studied on State of Learning Management based on the Philosophy of Sufficiency Economy of Teachers in Schools under Samut Songkhram Primary Educational Service Area Office, Mueang Samut Songkhram District, and found that state of leaning management based on the Philosophy of Sufficiency Economy of teachers on instructional activities management concerning instructional media and learning sources, measurement and evaluation was in high level for both overall picture and each dimension. After classifying based on learning areas and levels, it was found that operations of learning management under the Philosophy of Sufficiency Economy were not different for both overall picture and each dimension [10].

\section{DEFINITIONS}

1) Online lessons means a web-based lesson promoting the sufficiency economy philosophy in the online of students and anyone interested. Its contents are ordered in ordered from easy ones to difficult ones plus with practice and its answers in order to enable the students to know their results immediately. The students can learn by themselves upon their personal abilities.

2) Efficiency of Online lessons means capabilities of the web-based lesson in building the learning achievement of the target students from Faculty of Education, SSRU in order to enable them to obtain learning according to determined criteria of $80 / 80$.

The former 80 means efficiency of processes evaluated from the student's scores obtained from doing practices of each lesson during the class that is averagely $80 \%$.

The latter 80 means efficiency of the result evaluated from the scores of students for their post-test that is averagely $80 \%$ ".

3) Sufficiency has three components: moderation, reasonableness, and self-immunity, with two accompanying conditions: appropriate knowledge and ethics \& virtues.

4) Satisfaction of students means the feeling of students toward learning by using the sufficiency economy philosophy online lessons for sustainable learning. This satisfaction was measured by using 10 items of Satisfaction Questionnaire upon the likert's 5 rating scales.

\section{RESEARCH FRAMEWORK AND CONCEPT}

Research framework and concept is shown in Fig. 1.

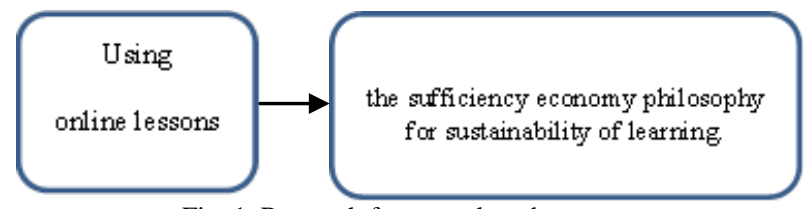

Fig. 1. Research framework and concept.

\section{RESEARCH PROCESS}

1) Studied papers and researches as well as studied from philosophers through interview and focus group in order to synthesize sufficiency economy philosophy. Subsequently, the obtained results were classified and arranged systematically in bi-language format (i.e., Thai and English) and created in the form of online lessons.

2) Submit developed the sufficiency economy philosophy online lessons for sustainable learning to experts for inspection and improvement.

3) Tried out improved the sufficiency economy philosophy online lessons for sustainable learning with students who were not target group for further improvement and public relations.

4) Students who were target group studied created the sufficiency economy philosophy online lessons for sustainable learning and took pre and post test. Subsequently, satisfaction of students was evaluated after their usage of the sufficiency economy philosophy online lessons for sustainable learning.

4.1. Tested students with test review of 3 online lessons. The obtained scores were collected as scores of formative evaluation.

4.2. 20 items of achievement test on online lessons were tested with students and the obtained scores were collected as scores of post-test.

4.3. 10 items of satisfaction evaluation form towards online lessons were commented by students.

5) The results were checked and the obtained scores of pre and post test were analyzed by using statistics in order to find efficiency at 80/80. 
6) Student's satisfaction after using the sufficiency economy philosophy online lessons for sustainable learning was analyzed and concluded

\section{CONCLUSION}

1) From development and try out of the sufficiency economy philosophy online lessons for sustainable learning, it was found that it was suitable and efficient according to defined criteria calculated to be $86.50 /$ 86.00 when utilizing with 40 students who were target group that was consisted with defined hypothesis.

2) From try out of the sufficiency economy philosophy online lessons for sustainable learning, it was found that efficiency of process (E1) provided in tests was calculated to be $86.50 \%$ and efficiency of results (E2) was calculated to be $86.00 \%$. These the sufficiency economy philosophy online lessons for sustainable learning had higher efficiency than $80 / 80$ as defined therefore it could be concluded that these online lessons had high efficiency as defined by criteria and they were able to be used for classroom instruction efficiently.

TABLE I: MEAN, STANDARD DEVIATION, AND SATISFACTION LEVEL OF STUDENTS TOWARDS THE SUFFICIENCY ECONOMY PHILOSOPHY ONLINE LESSONS FOR SUSTAINABLE LEARNING

\begin{tabular}{|c|c|c|c|c|}
\hline Item & Assessment List & mean & S.D. & $\begin{array}{l}\text { Satisfaction } \\
\text { Level }\end{array}$ \\
\hline 1 & $\begin{array}{l}\text { Explanation of the } \\
\text { sufficiency economy } \\
\text { philosophy was clear and } \\
\text { understandable. }\end{array}$ & 4.38 & 0.65 & High \\
\hline 2 & $\begin{array}{l}\text { Students understand contents } \\
\text { of the courses. }\end{array}$ & 4.33 & 0.67 & High \\
\hline 3 & $\begin{array}{l}\text { Procedures of the sufficiency } \\
\text { economy philosophy were } \\
\text { clear and appropriate. }\end{array}$ & 4.78 & 0.56 & Highest \\
\hline 4 & $\begin{array}{l}\text { Lesson starter was } \\
\text { appropriate. }\end{array}$ & 4.67 & 0.64 & Highest \\
\hline 5 & $\begin{array}{l}\text { Activities were appropriate } \\
\text { and interesting. }\end{array}$ & 4.6 & 0.8 & High \\
\hline 6 & Conclusion was appropriate. & 4.73 & 0.56 & Highest \\
\hline 7 & $\begin{array}{l}\text { Students were the center with } \\
\text { participation. }\end{array}$ & 4.4 & 0.7 & High \\
\hline 8 & $\begin{array}{l}\text { Students were able to ask } \\
\text { what questions with teachers. }\end{array}$ & 4.27 & 0.69 & High \\
\hline 9 & $\begin{array}{l}\text { Tests and practices were } \\
\text { appropriate. }\end{array}$ & 4.55 & 0.71 & High \\
\hline 10 & $\begin{array}{l}\text { Students required the } \\
\text { sufficiency economy } \\
\text { philosophy obtained from } \\
\text { online lessons in other } \\
\text { subjects. }\end{array}$ & 4.84 & 0.42 & Highest \\
\hline \multicolumn{2}{|c|}{ Overall Assessment } & 4.56 & 0.64 & High \\
\hline
\end{tabular}

3) From the results of student's satisfaction towards learning with the sufficiency economy philosophy online lessons for sustainable learning, it was found that overall student's satisfaction towards instruction using online lessons was in the highest level, i.e., students had overall satisfaction towards online lessons in high level with mean of 4.56 and item 10 was gained the highest satisfaction level of students. Average demand of students on creating online lessons for other subjects was
4.84. For other evaluations, most of them had high level of satisfaction.

From Table I, it was found that students who studied through online lessons had high level of satisfaction with the mean of 4.56 and Standard Deviation of 0.64. Students required the sufficiency economy philosophy obtained from online lessons in other subjects. and they also had the highest level of satisfaction with the mean of 4.84 and Standard Deviation of 0.42 . When considering on each item, it was found that most students had satisfaction in high level.

\section{Discussion}

From development and utilization of the sufficiency economy philosophy for sustainability of learning, the results could be discussed as follows:

Development and utilization of online lessons was successful and efficient as expected because the research had studied on process of making online lessons from several theories and concepts through studying on related papers and analyzing lesson's content from curriculum, determination of behavioral objective, planning of creation and development. Besides, the researcher was also supported by some content experts and their comments on index of consistency among issues, objectives, learning standard of curriculum, finding on accuracy of tools, and finding of confidence level, were assembled as a tool for creating and developing the sufficiency economy philosophy online lessons for sustainable learning. As a result, such online lessons were able to be created and developed successfully. Besides, they were also able to be used and publicized to other instructors in other universities that was consistent with a research of Sunanta Suntornprasert [11] stated that instruction with online lessons was able to develop students to be more confident with themselves and learn lessons with their potential leading to higher level of achievement. Besides, online lessons also developed students in both cognitive domain and affective domain efficiently because they enabled students to learn and understand contents of lessons through repeated reading. Besides, it was also found that online lessons were able to adjust learner's behavior to seek knowledge, realize, and see value of learning providing good cognitive skills to learners if such online lessons were developed by content expert and expert on online lessons correctly and systematically according to principles.

Efficiency of these online lessons was in high level as expected at 86.50 / 86.00 due to creation and development of such online lessons. The researcher studied on basic data and analyzed work, contents, learners who were target group, and behavioral objectives prior planning on creation and development to meet those behavioral objectives under explanation and suggestions of content expert for inspecting accuracy of contents, language correctness, appropriateness of design, instructional methods, and presentation. Subsequently, the obtained lessons were improved, developed, and tried out with a small student group in order to find further faults for additional improvement and development prior performing field tryout with 40 students. The results showed that efficiency of online lessons was $86.50 / 86.00$ that was satisfying and met with expected 
hypothesis.

Student's satisfaction towards the sufficiency economy philosophy online lessons for sustainable learning was in high level for all items because the research studied on psychology of learning of learners before planning creation of online lessons. Subsequently, the obtained results were planned for creation and development of complete online lessons that was consistent with work of Chaiwat Waree [12] who studied on Application Development on Tablet to Promote a Classroom Research Skills for SSRU'Students. The results showed that the efficiency of application on tablet was at $80.77 / 81.82$ that was higher than defined criteria at $80 / 80$. In addition, Overall satisfaction of students towards application on tablet usage was in the highest level.

\section{ACKNOWLEDGMENT}

This research was supported by Suan Sunandha Rajabhat University. Special thanks you to all experts and students of SSRU who helped and supported this project.

\section{REFERENCES}

[1] P. Wasee, National Intellectual Strategies, Bangkok : The Thailand Research Fund, 1995.

[2] K. Malaiwong, IT Perspective, National Electronics and Computer Technology Center, Ministry of Science and Technology, 1997.

[3] P. Sangchan, A Development of Online Lessons on Plant Life, Major of science For Prathomsuksa 4 Students, Master of Science Thesis Prince of Songkla University, 2008.

[4] J. A. Russett, "Using telecommunications with pre service teachers," Journal of computers in Mathematic and Science Teaching, 1992, pp. 65-76.
[5] J. M. Casey, Student Teacher Travel the Information Highway, [CDROM], ERIC Item: ED500403, 2018.

[6] R. Laroe, Moving to Virtual Curriculum, 1995.

[7] W. Pongcharoen, Effect of Computer Network Group Activities on Teamwork Behavior Grade 4 Students, Thesis Master of Education Naresuan University, 2004

[8] S. Julasawake, Research, Evaluation and Implementation of the Sufficiency Economy Philosophy in Schools, 2007.

[9] K. Duang-inthorn, "The opinions of school administrators, teachers and students on how to cultivate ethics for secondary school students in Department of General Education," Bangkok: Master's thesis, Chulalongkorn University, 1985.

[10] W Pansup, "A study of state of learning management in sufficiency economy of school teachers under Samut Songkhram Educational Service Area Office Amphoe Mueang Samut Songkhram," Master Thesis Srinakharinwirot University, 2008.

[11] S. Suntornprasert, Guidelines for Creating Instructional Innovation and instructional Module, Ratchaburi: Thammarak Printing, 2004.

[12] C. Waree, "Application development on tablet to promote a classroom research skills for SSRU' students," Challenges and Solutions in Smart Learning, 2018, pp. 21-24.

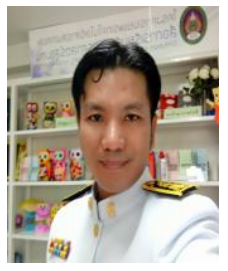

Chaiwat Waree was born in Nongchang, Thailand. He received the B.Ed. degree in Thai from the Srinakharinwirot University, TH, in 1999, the M.Ed. degree in guidance and counseling psychology from the Srinakharinwirot University, TH, in 2002, the D.Ed. degree in curriculum and instruction from the Burapha University, TH in 2010and the LL.B. degree in laws from Thammasat University, TH, in 2017.

His research interests cover the pedagogy and psychology and education technology and environment science.

Asst. Prof. Dr. Chaiwat is a lecturer at Faculty of Education, Suan Sunandha University and External assessor for Office of National Education Standards and Quality Assessment, TH. 